\title{
Trained and Non-Trained Language Teachers on CLIL Methodology: Teachers' Facts and Opinions about the CLIL Approach in the Primary Education Context in Spain
}

Capacitados y no capacitados en la metodología AICLE: datos y opiniones de los docentes sobre el enfoque AICLE en el contexto de educación primaria en España

Treinados e não treinados na metodologia AICL: dados e opiniões dos professores sobre a abordagem AICL no contexto do ensino primário em Espanha

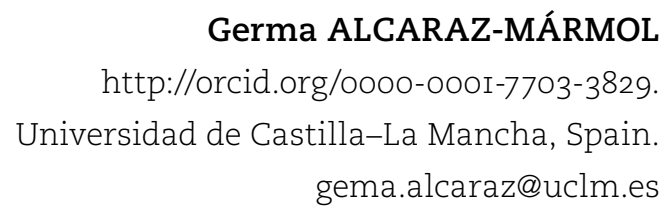

Received: 2018-06-26

Sent for peer review: 2018-07-25

Accepted by peers: 2018-08-23

Approved: 2018-08-23

To reference this article in APA style / Para citar este artículo en APA / Para citar este artigo Alcaraz-Mármol, G. (2018). Trained and non-trained language teachers on CLIL methodology: Teachers' facts and opinions about the CLIL approach in the primary education context in Spain. LACLIL, 11(1), 39-64. DOI: 10.5294/laclil.2018.11.1.3 
ABSTRACT. Since the early 2000s, there seems to be a growing interest in bilingual education in Spain. The need for teachers with certain accreditation in foreign language proficiency has been growing in the last decade. Yet, the methodological basis to integrate content and language in the classroom does not seem to be a compulsory requirement. The participants of this study were surveyed about several aspects of their teaching practice. We compared the answers of those who have received specific methodological CLIL training and those who have not. Results show that methodological training beyond just foreign language teaching makes significant differences in terms of the teachers' opinions on CLIL and practice of using bilingual practices in their classrooms, making use of a wider variety of activities and resources. Differences were found in the way they see their own teaching, their use of their L1, materials in the classroom, and the variety and type of activities they develop with their students.

Keywords: CLIL; primary education; teaching practice; bilingual education; teacher training.

RESUMEN. Hoy en día, parece haber un creciente interés en la educación bilingüe en España. La necesidad de contar con maestros con acreditación en un idioma extranjero ha venido aumentando en los últimos diez años. Sin embargo, la base metodológica para integrar el contenido y el lenguaje en el aula no parece ser un requisito obligatorio. Los participantes son encuestados sobre varios aspectos de su práctica docente. Comparamos las respuestas de aquellos que han recibido capacitación específica sobre el método AICLE y aquellos que no. Los resultados muestran que la capacitación metodológica más allá de la capacitación en idioma extranjero lleva a diferencias significativas en cuanto a las opiniones y la práctica de los docentes. Se encontraron diferencias en la forma en que ven su propio método de enseñar, su uso de la L1 y de los materiales en el aula, y el tipo de actividades que desarrollan con sus alumnos.

Palabras clave: AICLE; educación primaria; práctica docente; educación bilingüe; educación docente.

RESUMO. Atualmente, parece que há um interesse cada vez maior na educação bilíngue na Espanha. A necessidade de ter professores certificados em língua estrangeira vem aumentando nos últimos dez anos. No entanto, a base metodológica para integrar conteúdo e linguagem na sala de aula não parece ser um requisito obrigatório. Os participantes responderam a uma enquete sobre vários aspectos de suas práticas de ensino. Comparamos as respostas dos que receberam treinamento específico sobre o método AICL e aqueles que não receberam. Os resultados mostram que o treinamento metodológico, além da formação em línguas estrangeiras, leva a diferenças significativas nas opiniões e na prática dos professores. Encontramos diferenças na forma em que eles veem seu próprio método de ensino, seu uso da L1 e dos materiais na sala de aula, e o tipo de atividades que desenvolvem com seus alunos.

Palavras-chave: AICL; ensino primário; prática docente; educação bilíngue; formação de professores. 


\section{Introduction}

A document about multilingualism and development of linguistic competences published by the European Commission in 2014 invites member states to adopt measures aimed at increasing the effectiveness of language learning through innovative approaches and methods. In addition, the document points out the importance of evaluating the effectiveness of policies on multilingualism in the different member states and suggests rewarding and recognizing innovative practices in language teaching.

The bilingual programs in Spain date back to the agreement between the Ministry of Education and the British Council in 1996. The main objective of this agreement was to develop bilingual programs through the implementation of an integrated Spanish-British curriculum. Since then, this agreement has had different versions and the participation of many educational centers. The last version of this agreement was presented in 2013 and completed with some addendums in 2016. One of the main agents of the correct development of these programs is the teacher. Scholars claim for the need of teachers that are prepared to implement bilingual programs in a Content and Language Integrated Learning (CLIL) context (Julián, 2013; Melara \& González, 2016; Fleta, 2016). This profile of CLIL teacher implies deep knowledge of the foreign language, of the subject content as well as of the way to integrate both. While recommendations are arising about the need for methodological CLIL training programs, the Spanish law on education mainly focuses on the teacher's foreign language level and does not normally require specific methodological training for the implementation of CLIL.

The aim of our study is two-fold. On the one hand, a general view of a group of teachers' attitudes towards this approach and in class action is offered. On the other hand, we want to compare attitudes and teaching action of CLIL teachers who have specific CLIL methodological training and those who don't. We decided to conduct this study because we hypothesize that specific CLIL training makes a difference in teachers' attitudes towards CLIL and classroom practice. 
The study is organized as follows: The literature review section deals with the situation of CLIL in Spanish schools, which also explores different studies on teachers' attitudes towards CLIL from several scopes. Subsequently, the methodological section describes participants, the instrument of analysis and how data are analyzed. Finally, results will be presented and discussed, ending with concluding remarks and some limitations of the study to encourage further research.

\section{Literature Review}

\section{Content and Language Integrated Learning in Spanish Schools}

Halbach (2008) describes bilingual education as a "hazy concept" (p. 458), as it includes all types of different approaches that gather under this umbrella term. Within this umbrella term of bilingual education, we find CLIL. CLIL has been understood in different and diverse ways. Pérez (2016) sees CLIL conception as a "metaphorical pendulum" (p.12) with the definition swinging from identifying it with content-based instruction (CBI) to completely distinguishing it from the latter and proving them with a character that is completely different. Scholars such as Whittaker, Llinares, and McCabe (2011) identified CLIL with content-based instruction, that is, exclusively and technically instruction of content using the English language, with no attention to linguistic aspects. In the same vein, Cenoz (2015) opts for highlighting the similarities between content-based instruction, immersion, and CLIL. Karim and Rahman (2016) go even further and conclude that content-based instruction and CLIL are the same.

By contrast, other authors define CLIL as a dual approach in which foreign language and content are integrated (Coyle, Hood, \& Marsh, 2010). It is the proposed methodological model for developing the teaching of bilingual centers and refers to teaching through a foreign language with a double objective, namely the simultaneous learning of content and foreign language (Marsh, 1994), which would presumably lead to the transfer of teaching in a foreign language to teaching with 
and through that language (Eurydice, 2006). In other words, language is not only an object of learning, but also the medium that makes it possible, which implies an integrated curriculum (Cantero, 2008) in an innovative and alternative way to Communicative Language Teaching (Banegas, 2012). Thus, CLIL is to be distinguished from other bilingual methodologies, such as content-based instruction, as the latter mainly pursues content learning and where language learning is incidental. As can be seen, the definition of CLIL is still an open question. In fact, subscribing Cenoz, Genesse, and Gorter (2014), "the scope of CLIL is not clear-cut and, as a consequence, its core features cannot be clearly identified" (p. 247). What is more, the authors suggest that this is the reason why it is difficult for CLIL to be pedagogically consistent.

CLIL programs have been progressively adopted by primary and secondary schools throughout Spain. Additionally, more and more Spanish universities offer degrees in which the language of instruction is not Spanish. In fact, McDougald (2009) states that "schools and universities are not concerned with just learning English anymore, but are more concerned as to what students can do with the new language" (p. 44) This growing tendency towards teaching content through a foreign language is supported by the benefits that are advocated by many scholars.

Naves and Muñoz (2000) highlight the positive contribution of CLIL in the learning of both a foreign language and subject content, as well as the development of the students' solving problem skills. In a similar vein, Mehisto, Marsh, and Frigols (2008) point out that, in a CLIL context, students can use what they learn almost immediately, which motivates them and encourages them to keep on learning. They also mention the role of CLIL in meaningful learning and cognitive flexibility, providing a contextualized and natural context for learning.

The interest on CLIL has brought about a change in the conceptualization of teaching and consequently in teacher training. Given the dual nature of the CLIL approach, training should contemplate both foreign language and subject matter methodological and pedagogical knowledge. Research remarks that teacher training and teaching skills are key elements for the implementation and success of bilingual education (Dafouz, Núñez, Sancho, \& Foran, 2007; Coyle et al., 2010; Aguilar \& Rodríguez, 2012; Fortanet-Gómez, 2012; Martín del Pozo, 2015). 
As the bilingual programs started to be adopted by schools, the teachers' linguistic training became an urgent issue. The future bilingual schools needed professionals that were able to give content lessons of several subjects in a foreign language. As Sierra and López (2015) affirm, "the transfer of content in a second language implies a huge effort, thorough pacification, [however] training could be not enough, having a (negative) impact on the Primary Education students" (p. 89, our translation). Pavón and Gaustad (2013) highlight that "teaching through a second language advocates the use of methodological strategies to promote interaction and language use in the classroom as the main means for students to access information" (p. 84). Indeed, bilingual teaching consists of transmitting knowledge in a foreign language, and as such, being proficient in that language is essential but not enough. Therefore, future teachers should receive specific methodological training, which can provide them with solid knowledge on theoretical and practical CLIL principles (Sierra \& López, 2015).

The education law in most of the Spanish regions addresses the language level requirements of teachers that develop their teaching activity in a CLIL context. Guadamillas and Alcaraz (2017) analyze the Spanish legislation about bilingual teaching. One of the aspects under analysis is the different certifications that teachers need to have as part of a bilingual teaching program. In most regions, teachers must have at least a B2 level, according to the Common European Framework, of the foreign language that they use to develop content in the classroom. There are some exceptions, such as the cities of Madrid and Navarra, where the minimum language level for teaching in a CLIL context is C1. Nonetheless, more and more regions tend to require a linguistic level of proficiency higher than B2. In fact, though not an indispensable condition, Andalucía strongly recommends the $\mathrm{C} 1$ level of proficiency for CLIL teachers in its Order of 28 June 2011. What is more, the latest decree of Castilla-La Mancha published in February 2018 states that primary and secondary school teachers in this region must have a C1 level of the foreign language of instruction for bilingual teaching.

As for methodological training on the CLIL approach, the situation in different regions is more heterogeneous. The study carried out by Guadamillas and Alcaraz (2017) shows that legislation is less demanding regarding the methodological teachers' requirements. Although there are some exceptions, such as Cantabria, the Canary Islands or 
La Rioja-where methodological CLIL training is explicitly required by the law- about half of the Spanish regions, such as Catalonia, Galicia or Aragón, do not mention any methodological requirement for CLIL teachers, just certain linguistic proficiency. The others mention methodological training, although they do not present it as a requirement but rather as a suggestion. This is the case of Murcia and Castilla-La Mancha. In the former, according to Article 24 of Order of 3 June 2016, the participation of teachers in CLIL activities and courses is an indicator of the correct development of the bilingual programs. Decree $47 / 2017$ of the latter states that the local government would elaborate a program specifically designed for the methodological training of CLIL

\section{Attitudes towards CLIL}

The implementation of CLIL programs in Spanish schools has not been free from discussion. Scholars have carried out studies based on opinion surveys, as “by doing so [research based on attitudes' stakeholders towards CLIL], decision makers would gain access to valuable information that would help them make better-informed decisions regarding the implementation of CLIL" (McDougald, 2015, p. 26). Massler (2012) states that "the perspectives of learners, parents and teachers inform and illuminate the very conditions of learning and teaching" (p. 36). Several studies show that students, parents, and teachers agree on the benefits of CLIL methodology, such as a variation of activities as a tool to higher student proficiency in both language and content, and are highly motivated when talking about it. They agree that CLIL is positive and enriching for learning. (Fernández et al., 2005; Laorden \& Peñafiel, 2010; Mell et al., 2013; Coyle, 2006).

In primary and secondary education, families have an important role when it comes to choosing a school for their children. Parents, as well as teachers, consider bilingual education to be an element of distinction for teaching institutions (Fernández, Pena Díaz, García Gómez, \& Halbach, 2005; Laorden \& Peñafiel, 2010; Mell, Bolarín, \& Porto, 2013). At the same time, teachers find bilingualism to be a means of recycling, an expectation of change and an opportunity for improvement. Research carried out by Coyle (2006) and San Isidro (2009) shows that they believe that CLIL lessons become a good scenario for methodological 
improvement and new challenges. Yet, teachers and students do not always seem so enthusiastic with regard to taking part of the program itself and teaching or being taught within the CLIL framework (Dafouz et al. 2007; Borrull, Catrain, Juan, Salazar, \& Sánchez, 2008; Yassin, Marsh, Tek, \& Ying, 2009; Massler, 2012; Sancho-Esper, Ruíz-Moreno, Rodríguez-Sánchez, \& Turino, 2016).

Focusing on teachers, one of the reasons why they don't feel completely comfortable teaching content through a foreign language is related to the fact that they lack a methodological basis (Savic, 2010; Johnson, 2012; McDougald, 2015). Pavón and Rubio (2010) list the three main uncertainties of teachers that have to teach in a CLIL context, namely, classroom methodology, theoretical assumptions on bilingual education and the implementation of the integrated curriculum. All these aspects belong to the methodological part of teacher training. Amat, Vallborna, and Martí (2017) carried out a study where future primary education teachers were asked about teaching science through English. The participants expressed negative emotions when visualizing themselves as CLIL teachers. They showed uncertainty and fear when they imagined themselves using the foreign language. Yet, their main insecurities were expressed in how to integrate language and content to make sure children reach the established learning goals.

Lorenzo, Casal, Moore, and Alfonso (2009) explored the attitudes and beliefs of teachers in bilingual schools of Andalucía. They wanted to know the teachers' opinions about linguistic and methodological training, coordination and resources. Among all the aspects to be improved, methodological CLIL training was the most urgent, according to the teachers' opinions, followed by more clear and specific guides on bilingual programs.

Given this situation expressed by many CLIL teachers, scholars claim for a greater implication of the institutions suggesting some measures so that quality methodological training can be accessible. Hillyard (2011) observed that "content teachers are not infrequently monolingual [...], while language teachers may not feel proficient in the subject-area knowledge required for content teaching" (p. 1). That is why she advocates for a "workforce sufficiently competent" (Hillyard, 2011, p.1) in terms of both the target language and subject content. Lova, Bolarín, and Porto (2013) advocate for better options of teacher CLIL training in the Region of Murcia. Ramos (2007) poses some measures for correct teach- 
ing practice that are based in training and updating. The author urges to train qualified professionals who not only are proficient in the foreign language of instruction, but who are familiar with specific techniques and strategies for the integrated teaching of content and language. This is in line with Banegas (2012), who hinges on the need to provide CLIL teachers with training on bilingual education methodologies. Similarly, Cancelas and Cancelas (2009) offer some guidelines to apply CLIL in the area of music. For their part, Fernández (2009) and Molero (2011) explain how to integrate and sequence content and language in physical education class. Cabezuelo and Fernádez (2014) affirm that significant advances on CLIL teacher training have been achieved, but more should be done in order to be fully successful in this type of bilingual education.

It is within this context that our study is framed. It aims to explore the attitudes of a group of primary education teachers who develop their practice in a CLIL classroom, comparing those who have received specific CLIL training and those who have not.

\section{Method}

\section{Participants}

A list of state elementary schools in the Region of Murcia was done based on the data provided by the Department of Education of Murcia. The survey was initially sent by email to 57 schools with 75 primary education teachers, 60 of whom answered. We found both women and men who teach students from 6 to 12 years of age and have between 3 and 10 years of experience in CLIL education. All of them have studied the degree of Primary Education Teaching and have a B2 level of English.

\section{Instrument}

A survey was designed ad hoc and was electronically sent to the teachers by means of Google Drive. It was written in Spanish and was divided into three blocks. The survey was based on closed-ended questions, al- 
though there was an open option called "others" where teachers could give an open answer that was not contemplated by the researchers.

The first block asked for personal and professional informationthat is, age, gender, years of experience, and academic training. The second part of the survey contained questions about the way CLIL was applied in the classroom. Teachers were asked about their opinion on the use of CLIL in general, their development of CLIL methodology in particular, the use of the foreign language, the role of the L1 in the classroom, the activities students did, and additional teaching materials.

The last set involved three questions about the teachers' opinion on the efficacy of the CLIL approach. Teachers were asked whether they considered the CLIL approach provided a good context for both foreign language learning and content, just for foreign language learning, just for content, or for none of them. They were also asked whether CLIL could harm the students' learning of content. With the last question, we wanted to know if the teachers thought that the language of instruction made any difference in the way content was learned.

\section{Data analysis}

Both descriptive and inferential statistics were used for data analysis. Descriptive statistics allowed us to offer averages and percentages, whereas with inferential statistics we compared the attitudes of those teachers who received CLIL training and those who didn't. We carried out two inferential operations. ANOVA and Mann-Whitney tests were used. The former was applied for the results of the yes/no questions. It is not possible to use ANOVA for questions with more than two options. Consequently, the non-parametric Mann-Whitney test was an option for this questions that adopted a multiple-choice format.

\section{Results}

\section{First block: Participants' profile}

We find that $66.6 \%$ of women and $33.3 \%$ men between the ages of 28 and 50 years old completed the survey. Approximately $43.4 \%$ of the 
teachers are in their 40s. The teachers in their 30s amount to $36.6 \%$. Only $20 \%$ are less than 30 . The content subjects taught by the participants are science $(45 \%)$, social sciences $(22 \%)$, physical education (20\%), music and art (13\%). More than $67 \%$ of the surveyed teachers have worked within a CLIL context between 5 and 10 years. Around 23.7\% have more than 10 years of CLIL experience, and only 5 teachers $(8.3 \%)$ are new to CLIL teaching with less than 5 years of experience. As for experience abroad, 10 teachers (16.6\%) have worked in the United Kingdom doing something other than teaching, and 20 teachers (33.3\%) have had short stays in an English-speaking country, taking some language course. Almost half of the participants (45\%) had received specific training in CLIL methodology, during their university years as part of their degree or later by means of specific courses when they were already in-service teachers. The rest are autodidact and tried to learn about this approach on their own. They all have a degree in Primary Education.

\section{Second block: CLIL in the classroom}

Teachers were asked whether or not they thought that, in general terms, CLIL methodology is applied adequately. Up to $65 \%$ did not consider that CLIL was being developed in a correct way. Only 35\% answered positively to this question. Yet, when they were asked about their particular use of this methodology in class, $70 \%$ thought that they carried out an adequate implementation of CLIL, and only around one third of teachers (30\%) were critical towards their own performance (Figure 1).

We also wanted to know the role of L1 and L2 in the class discourse. As for the question In which situations do you use your L1 (Spanish)?, all teachers used L1 to a certain extent. None of the participants chose the option "I never use the L1." L1 was mostly used to resolve doubts (45\%) and for extracurricular teacher-student conversations inside the classroom (41.6\%). Yet, 13.4\% admitted to explaining subject content in L1 (Figure 2).

As for activities and materials developed in the CLIL context, data reveal that controlled activities are more widely used than semi controlled or free production activities. Among controlled formats, we find multiple-choice (85\%), matching (80\%), and gap filling (70\%) activities. 
Figure 1. Correct implementation of CLIL methodology

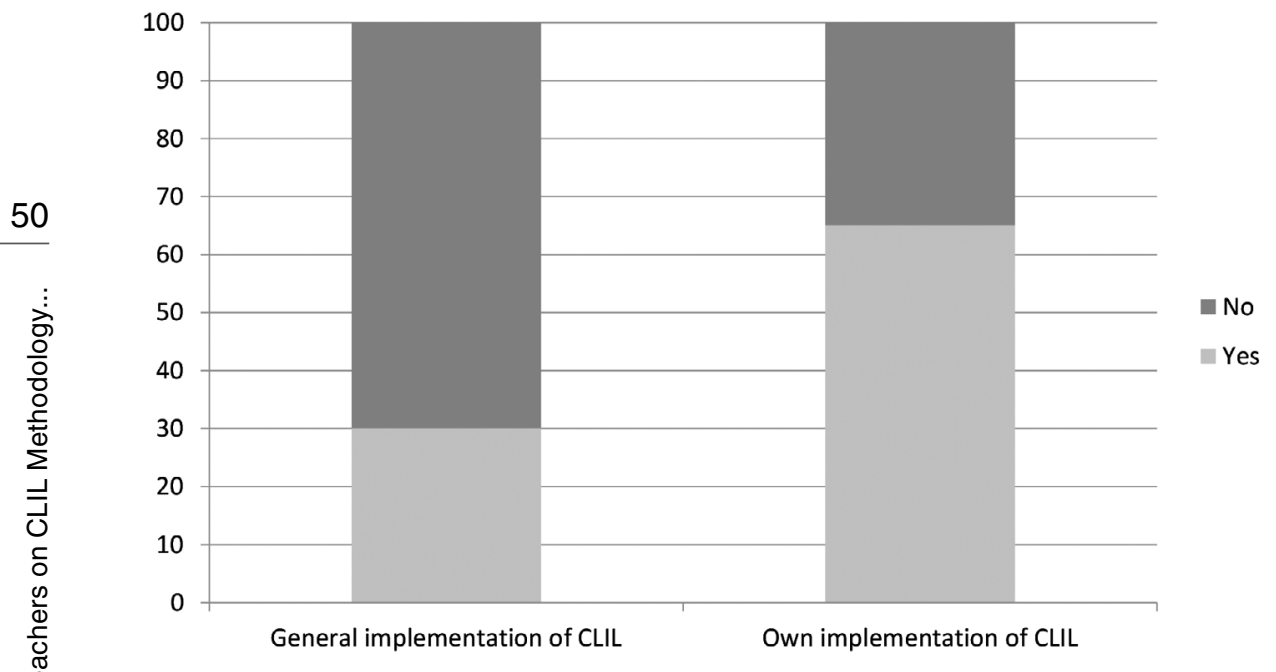

Figure 2. Use of $L 1$ in the classroom

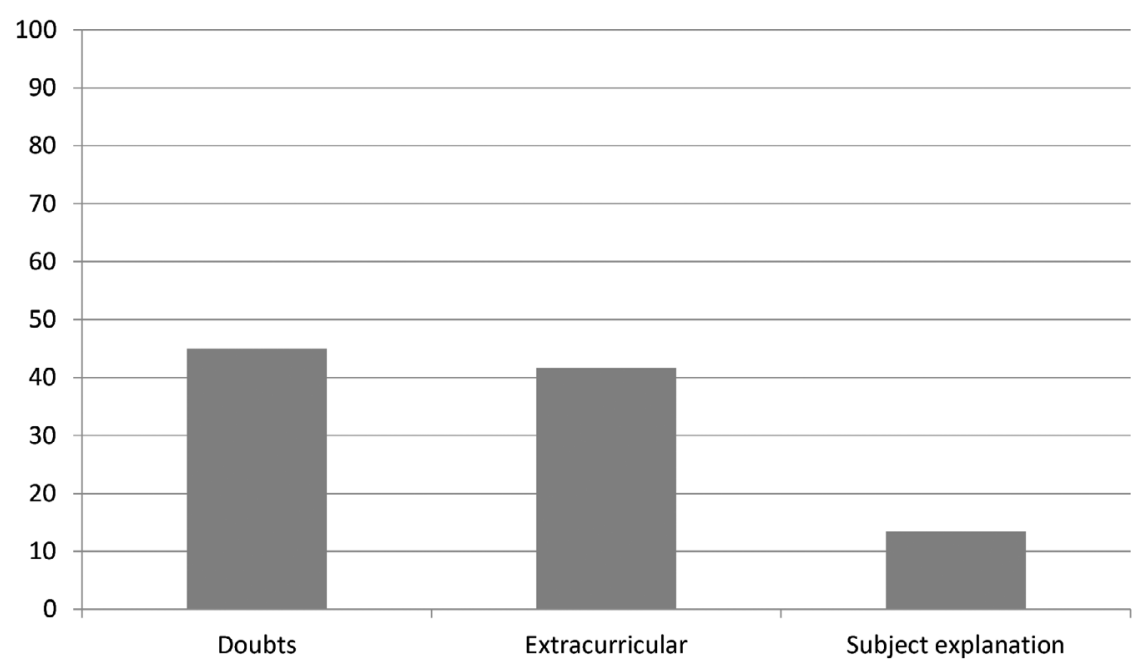

Source: Own elaboration. 
The semi-controlled activities carried out in class are drawing while following instructions (23\%), oral presentation (18.7\%), short writing with the help of clues (12.3\%), and oral debate (10.7\%) (Figure 3). As for additional materials, $40 \%$ teachers affirmed that they normally work with videos and CDs beyond the textbook.

Figure 3. Type of activities developed by CLIL teachers in the classroom

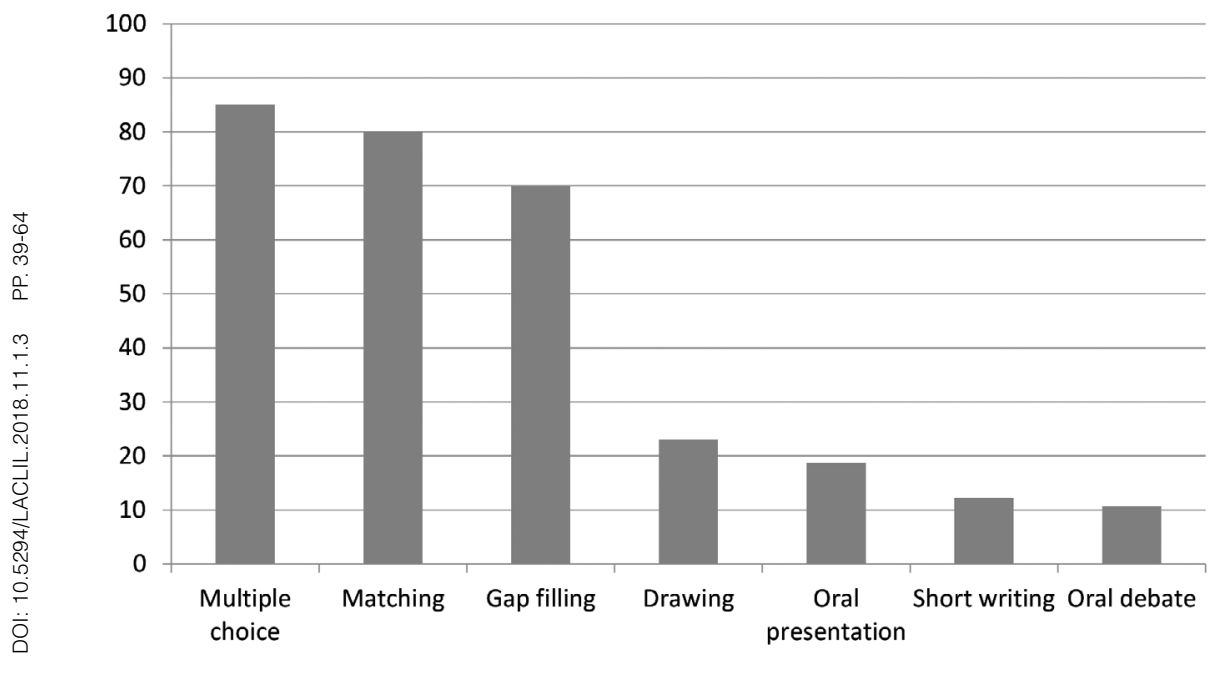

Source: Own elaboration.

\section{Third block: Efficacy of the CLIL approach}

In this last block, teachers answered three questions related to their views on the efficacy of CLIL for content and foreign language learning. In the first question, half of the teachers (50\%) thought that CLIL was efficient for the learning of both foreign language and content. By contrast, $41.7 \%$ consider CLIL as a good methodology for foreign language learning but not for content, and 8.3\% did not see CLIL as useful for either foreign language learning or content (Figure 4).

The second question of this block pointed towards the idea that content learning in the L2 can become as deep and detailed as in the L1. In this case, almost 65\% (64.7\%) disagreed. They admitted to believing that content learning in the L2 was not as deep and detailed for students as the same content in the L1 (Figure 5). 
Figure 4. Is CLIL efficient for the learning of foreign language and content?

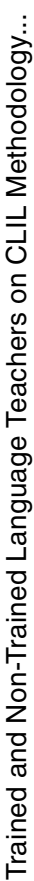

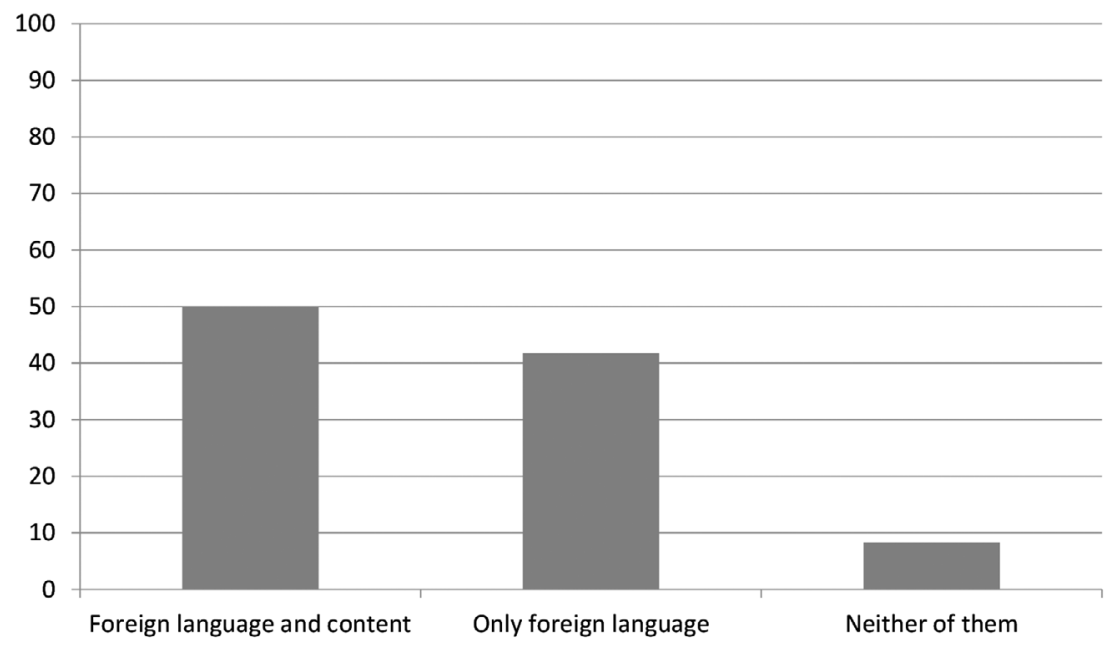

Source: Own elaboration.

Figure 5. Content learning can be as deep under CLIL instruction

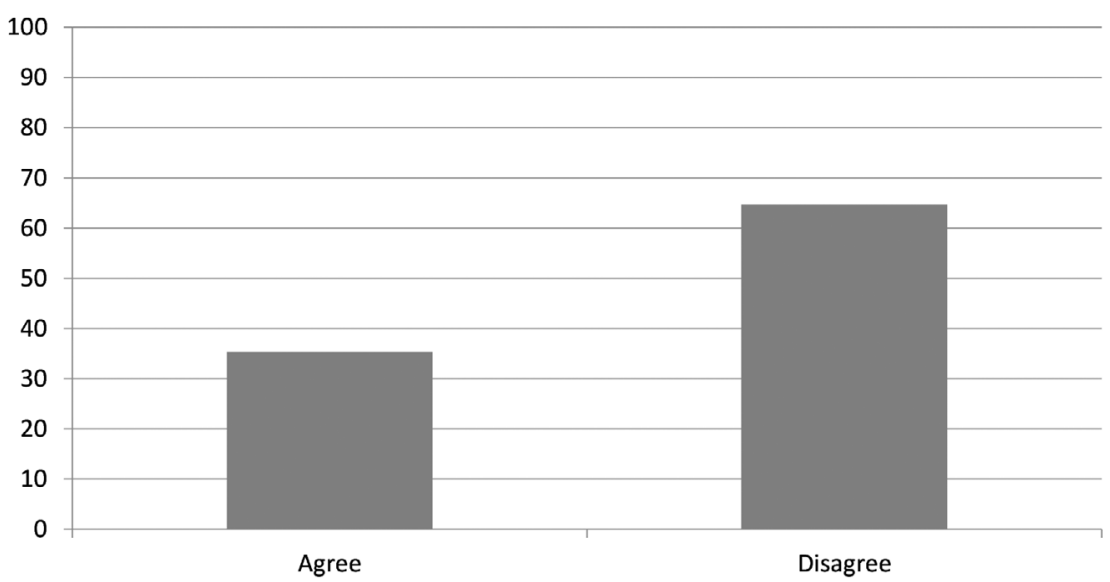

Source: Own elaboration. 
Finally, we wanted to know the teachers' opinion about the idea that CLIL can disfavor the learning of subject content. Half of the teachers surveyed (50\%) agreed with the idea that CLIL can partly become unfavorable for content learning, 15\% admitting they thought this methodology to be completely unfavorable. Only around 35\% thought CLIL could by no means disfavor students' content learning (Figure 6).

Figure 6. Can CLIL disfavor content learning?

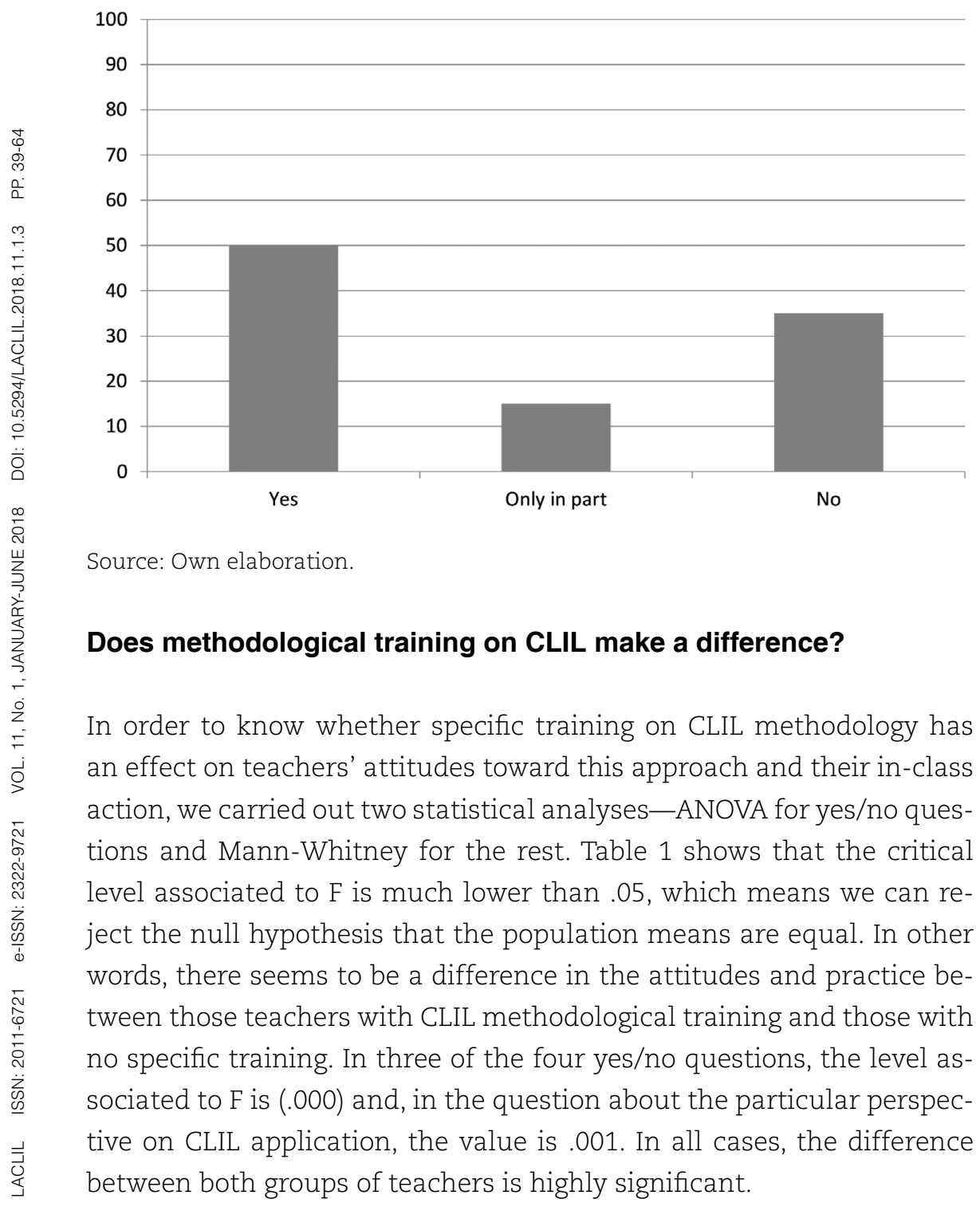


Table 1. ANOVA analysis comparing teachers with and without methodological CLIL training

\begin{tabular}{|c|c|c|c|c|c|c|}
\hline \multicolumn{2}{|c|}{} & $\begin{array}{c}\text { Sum of } \\
\text { squares }\end{array}$ & df & $\begin{array}{c}\text { Quadratic } \\
\text { mean }\end{array}$ & F & Sig \\
\hline \multirow{3}{*}{ Gral_Use_CLIL } & Inter-groups & 6.014 & 1 & 6.014 & 45.675 & .000 \\
\cline { 2 - 8 } & Intra-groups & 7.636 & 58 & .132 & & \\
\cline { 2 - 8 } & Total & 13.650 & 59 & & & \\
\hline \multirow{3}{*}{ Part_Use_CLIL } & Inter-groups & 2.150 & 1 & 2.150 & 12.426 & .000 \\
\cline { 2 - 8 } & Intra-groups & 10.034 & 58 & .173 & & \\
\cline { 2 - 8 } & Total & 12.183 & 59 & & & \\
\hline \multirow{3}{*}{ Material } & Inter-groups & 10.023 & 1 & 10.023 & 132.811 & .001 \\
\cline { 2 - 8 } & Intra-groups & 4.377 & 58 & .075 & & \\
\cline { 2 - 8 } & Total & 14.400 & 59 & & & \\
\hline \multirow{3}{*}{ Depth_knowlege } & Inter-groups & 4.808 & 1 & 4.808 & 34.113 & .000 \\
\cline { 2 - 8 } & Intra-groups & 8.175 & 58 & .141 & & \\
\cline { 2 - 8 } & Total & 12.983 & 59 & & & \\
\hline
\end{tabular}

Source: Own elaboration.

The results of the Mann-Whitney test for the multiple-choice items of the survey are shown in Table 2.

Table 2. Mann-Whitney analysis comparing teachers with and without methodological CLIL training

\begin{tabular}{|l|c|c|c|c|}
\hline & Type_Act & Use_L1 & Disf_learning & Efficiency \\
\hline Mann-Whitney U & 181.000 & 136.000 & 276.000 & 40.500 \\
\hline Wilcoxon W & 559.000 & 514.000 & 837.000 & 418.500 \\
\hline Z & -4.409 & -5.035 & -2.766 & -6.686 \\
\hline Asymp. Sig (2-tailed) & .000 & .000 & .006 & .000 \\
\hline
\end{tabular}

${ }^{*}$ Grouping variable: training

Source: Own elaboration.

As can be observed, the Asymp.Sig factor (.000) for the grouping variable-in this case, training-indicates that there are significant differences between the opinions and actions of CLIL teachers that have methodological training and those who don't for three of the four items: type of activities, use of the L1, and CLIL efficiency for learning. Yet, there do not seem to be differences between the two groups of teachers as regards the possible negative CLIL effect on content 
learning. Regardless of the presence or absence of CLIL methodological training, many teachers thought that CLIL might become non-favorable for content learning to some extent.

\section{Discussion}

Our hypothesis was that specific CLIL training is a significant variable in CLIL teachers' and that it makes a difference in their attitudes towards CLIL and their classroom practice, with a higher variety of activities and resources. Natural Science is the subject that is taught in most cases. This subject is the most taught not only in Murcia, but in many other regions, where this subject is one of the options or even requirements to be taught in the foreign language (Tobalina, Carbonero, \& Martínez 2017). The surveyed teachers' teaching experience on CLIL ranges between 5 and 10 years.

Despite the general interest in bilingualism and the promotion of the national and the regional governments in this issue, less than half of the surveyed teachers have had some experience abroad. What is more, only in one third of these cases the experience has been particularly related to the teaching activity or teacher training. In relation to this issue, it is important to point out that the number of teachers that have some specific training on CLIL methodology does not reach $50 \%$. However, we did not ask participants to specify the duration or type, which is a limitation of the study. A follow-up interview for those who did receive any training would have significantly improved our study.

Methodological training on CLIL seems to make a difference between the two teacher groups. Most teachers who thought that CLIL was not applied in a correct way had been methodologically trained. As for the teachers' perception on their own teaching, they seem to be happy with the way they apply the CLIL methodology. Yet, their attitude is not positive when asked about the implementation of CLIL by other teachers. This attitude might be due to the idea of CLIL that each teacher has. As stated above, CLIL can be considered an umbrella term, sometimes identified with content-based instruction or even immersion (Halbach, 2008; Whittaker et al., 2011; Cenoz, 2105). In fact, 
Halbach (2008) warns that there is a lack of explicit CLIL methodology, which forces teachers to apply their ad hoc ways of proceeding. Therefore, we could expect the surveyed teachers to think that their way of implementing CLIL is the correct way, contrary to the way other teachers develop their lessons. In fact, many of these approaches may not correspond to what is expected in CLIL. Pavón and Gaustad (2013) affirm that "there are many misconceptions and erroneous assumptions that lead some to consider that these programs can be implemented simply by changing the language in which the subjects are taught" (p. 82). However, this would be more in the line of content-based rather than CLIL (Coyle et al., 2010). The lack of knowledge of the methodological principles of CLIL on the part of some teachers can be one of the reasons of the diversity of opinions about how CLIL methodology should be developed in class. As for particular CLIL practice, most of the teachers who thought they did not use CLIL correctly belonged to the non-trained group.

Differences were found in the use of additional materials. Whilst most trained teachers used materials other than the textbook, those without methodological training based all their teaching on the textbook. Many teachers-both methodologically trained and nontrained-opt for controlled written activities. Yet, those who also used semi-controlled and free production oral activities were those who belonged to the trained group. Differences are also observed in the use of the L1. The teachers' L1 is used by both groups. However, it is less used by the trained teachers, who limit their usage to solving doubts and extracurricular discourse. By contrast, non-trained teachers tend to use the L1 in more occasions and also some of them use it for content explanation. This leads us to acknowledge Hillyard's (2011) claims for educational programs for teachers that include specific modules on curricular planning.

A similar picture is found as regards opinions on CLIL efficiency. Most trained teachers thought that CLIL was efficient for the learning of both foreign language and content, as opposed to what the group of non-trained teachers thought. They considered that this approach did not guarantee that students would learn content with the same guarantee as they would in the L1. Yet, both groups shared the idea that, to some extent, the L2 might be a problem for some children, and 
that this can somewhat affect their content learning process. That is why scholars such as Banegas (2012) highlight the importance of CLIL teacher education, so that this workforce can lead with the different situations that may occur in the CLIL classroom and warrant a quality education for students.

Cabezuelo and Fernández (2014) point out that CLIL teachers will have to be adequately trained in this methodology, and that there is a need for more and better CLIL courses. In fact, Mehisto et al. (2008) list a series of skills that CLIL teachers should have. Among them, we find the explicit mention of knowledge of the methodology to integrate language and content. Halbach (2008) explains that most of the CLIL projects carried out in Spain and the rest of Europe are designed ad hoc-that is, no methodological basis is adopted. Indeed, those projects mainly consisted in teaching content using a L2 as the vehicular language instead of the students' L1. The author suggests coordination between different subjects as the first step to create a methodology across the different content and linguistic subjects, so that it responds to the linguistic needs of the content subject at the same time it guarantees an adequate development of the foreign languages.

\section{Conclusions}

The present study shows the attitudes of a group of CLIL teachers in primary education within the Spanish context. First, the teachers' ideas and practice about CLIL are offered. Then, the comparison between the ideas and practice of those teachers who had received specific methodological training on CLIL and those who don't is carried out. Results show that there are significant differences between both groups.

Trained teachers have a more clear idea on what CLIL is and how to implement it, using a wider variety of resources and activities. Therefore, our results suggest that CLIL methodological training should be as important as linguistic training. It should tend towards being compulsory rather than just recommended, adopting the same status as the linguistic certification that is required when implementing this approach. 


\section{References}

Aguilar, M., \& Rodríguez, R. (2012). Lecturer and student perceptions on CLIL at a Spanish university. International Journal of Bilingual Education and Bilingualism, 15, 183-197.

Amat, A., Vallborna, A., \& Martí, J. (2017). Percepciones de futuros maestros de infantil y primaria sobre la enseñanza y el aprendizaje de las ciencias en inglés. Enseñanza de las Ciencias, Special Issue, 4931-4936.

Banegas, D. L. (2012). CLIL teacher development: Challenges and experiences. Latin American Journal of Content \& Language Integrated Learning, 5, 46-56.

Barcelona European Council. (2002). Presidency conclusions. Retrieved from http://www.consilium.europa.eu/ueDocs/cms_Data/docs/pressData/en/ec/71025.pdf

Borrull, M. N., Catrain, M., Juan, M., Salazar, J., \& Sánchez, R. (2008). La enseñanza del inglés como lengua extranjera basada en contenidos. Percepciones del profesorado de educación secundaria en las Islas Baleares. Revista Electrònica d'Investigació i Innovació Educativa i Socioeducativa, 1, 105-128.

Cabezuelo, P., \& Fernández, R. (2014). A case study on teacher training needs in the Madrid bilingual project. Latin American Journal of Content and Language Integrated Learning, 7(2), 50-70.

Cancelas, L. P., \& Cancelas, M. A. (2009). AICLE: estableciendo las bases para trabajar la música en L2. TAVIRA, 25, 137-159.

Cantero, V. (2008). El aprovechamiento de la «integrabilidad» en el proceso de transferencia lingüísticas de la L1 a la L2 o como potenciar la interactividad de las lenguas en los procesos comunicativos del modelo educativo bilingüe. Didáctica. Lengua y Literatura, 20, 37-60.

Cenoz, J. (2015). Content-based instruction and content and language integrated learning: The same or different? Language, Culture and Curriculum, 28, 8-24.

Cenoz, J., Genesse, F., \& Gorter, D. (2014). Critical analysis of CLIL: Taking stock and looking forward. Applied Linguistics, 35, 243-262.

Coyle, D., Hood, P., \& Marsh, D. (2010). CLIL - Content and Language Integrated Learning. Cambridge, UK: Cambridge University Press. 
Coyle, D. (2006). Content and Language Integrated Learning. Motivating learners and teachers. Scottish Languages Review, 13, 1-18.

Dafouz, E., Núñez, B., Sancho, C., \& Foran, D. (2007). Integrating CLIL at the tertiary level: Teachers' and students' reactions. In D. Wolff, \& D. Marsh (Eds.), Diverse contexts converging goals. Content and language integrated learning in Europe (pp. 91-102). Frankfurt, Germany: Peter Lang.

Decree 47/2017, which regulates the plan for foreign language teaching in Castilla-La Mancha. Official Bulletin of Castilla-La Mancha, Toledo, Spain, 25 July 2017.

Eurydice. (2006). Content and Language Integrated Learning at school in Europe. Retrieved from http://www.indire.it/lucabas/lkmw_file/eurydice/ CLIL_EN.pdf

Fernández, E. (2009). La secuenciación de contenidos lingüísticos dentro de la educación física bilingüe. Revista Digital Innovación y Experiencias Educativas, 23, 1-9.

Fernández-Fernández, R., Pena-Díaz, C., García-Gómez, A., \& Halbach, A. (2005). La implantación de proyectos educativos bilingües en la Comunidad de Madrid: las expectativas del profesorado antes de iniciar el proyecto. Porta Linguarum, 3, 161-173. Retrieved from https:// dialnet.unirioja.es/servlet/articulo? codigo=1153792

Fleta, M. T. (2016). El aprendizaje de lenguas extranjeras en educación infantil en la Comunidad de Madrid: perfil, percepciones y metodologías de los docentes. Didáctica. Lengua y Literatura, 28, 87-111.

Fortanet-Gómez, I. (2012). Academics' beliefs about language use and proficiency in Spanish multilingual higher education. Aila Review, 25, 48-63.

Guadamillas, V., \& Alcaraz, G. (2017). Legislación en enseñanza bilingüe: análisis en el marco de educación primaria en España. Revista Multiárea, 9, 82-103.

Halbach, A. (2008). Una metodología para la enseñanza bilingüe en la etapa de primaria. Revista de Educación, 346, 455-466.

Hillyard, S. (2011). First steps in CLIL: Training the teachers. Latin American Journal of Content \& Language Integrated Learning, 4(2), 1-12.

Johnson, M. (2012). Bilingual degree teacher's beliefs: A case study in a tertiary setting. Pulso Revista de Educación, 35, 49-74.

Julián, C. (2013). La coordinación docente en modelos AICLE. Revista Padres y Maestros, 349, 21-24. 
Karim, A., \& Rahman, M. (2016). Revisiting the content-based instruction in language teaching in relation with CLIL: Implementation and outcome. International Journal of Applied Linguistics and English Literature, 5, 254-264.

Laorden, C., \& Peñafiel, E. (2010). Proyectos bilingües en los centros de la Comunidad de Madrid: Percepción de los equipos directivos. Revista de Investigación Educativa, 28, 325-344.

Lorenzo, F., Casal, S., \& Moore, P. (2009). The effects of Content and Language Integrated Learning in European education: Key findings from the Andalusian bilingual sections evaluation project. Applied Linguistics, 31, 418-442.

Lova, M., Bolarín, M. J., \& Porto, M. (2013). Programas bilingües en educación primaria: valoraciones de docentes. Porta Linguarum, 20, 253-268.

Marsh, D. (1994). Bilingual education \& Content and Language Integrated Learning. In International Association for Cross-cultural Communication (Eds.), Language Teaching in the Member States of the European Union (Lingua). Paris, France: University of Sorbonne.

Martín del Pozo, M. (2015). Teacher education for content and language integrated learning: Insights from a current European debate. Revista Electrónica Interuniversitaria de Formación del Profesorado, 18, 153-168.

Massler, U. (2012). Primary CLIL and its stakeholders: What children, parents and teachers think of the potential merits and pitfalls of CLIL modules in primary teaching. International CLIL Research Journal, 1, 36-46.

McDougald, J. (2015). Teachers' attitudes, perceptions and experiences in CLIL: A look at content and language. Colombian Applied Linguistic Journal, 17, 25-41.

McDougald, J. (2009). The state of language and content instruction in Colombia. Latin American Journal of Content and Language Integrated Learning, 2, 44-48.

Mehisto, P., Marsh, D., \& Frigols, M. (2008). Uncovering CLIL: Content and Language Integrated Learning and bilingual and multilingual education. Oxford, UK: MacMillan.

Melara, F. J., \& González, I. (2016). Trazos para el diseño del perfil competencial de la figura del maestro bilingüe. Revista Española de Pedagogía, 264, 357-380. 
Mell, M. L., Bolarín, M. J., \& Porto, M. (2013). Programas bilingües en educación primaria: valoraciones de docentes. Porta Linguarum, 20, 253-268.

Molero, J. J. (2011). La planificación de la educación física bilingüe: aspectos a tener en cuenta en la integración de los contenidos lingüísticos. Emásf. Revista digital de Educación Física, 9, 6-15.

Naves, T., \& Muñoz, C. (2000). Implementation of CLIL in Spain. In D. Marsh, \& G. Langé (Eds.), Implementing Content and Language Integrated Learning (pp. 145--158). Jyväskylá, Finland: ER-paino \& Jyväskylänyliopistapaino.

Order 28 June 2011, which regulates bilingual teaching in Andalusia. Official bulletin of Andalusia, Seville, Spain, 28 June 2011.

Order 3 June 2016, which regulates foreign language teaching in the Region of Murcia, Murcia, Spain, 3 June 2016.

Pavón, V., \& Gaustad, M. (2013). Designing bilingual programmes for higher education in Spain: Organizational, curricular and methodological decisions. International CLIL Research Journal, 2, 82-94.

Pavón, V., \& Rubio, F. (2010). Teachers' concerns and uncertainties about the introduction of CLIL programmes. Porta Linguarum, 14, 45-58.

Pérez, M. L. (2016). From the CLIL craze to the CLIL conundrum: Addressing the current CLIL controversy. Bellaterra Journal of Teaching and Learning Language and Literature, 9(1), 9-31.

Ramos, F. (2007). Programas bilingües y formación de profesores en Andalucía. Revista Iberoamericana de Educación, 44, 133-147.

San Isidro, X. (2009). Galicia: CLIL success in a bilingual community. In D. Marsh, P. Mehisto, D. Wolff, R. Aliaga, T. Asikainen, M. J Frigols-Martin, S. Hughes, \& G. Langé (Eds.), CLIL practice: Perspectives from the field (pp. 57-78). Jyväskylä. Finland: University of Jyväskylä.

Sancho-Esper, F., Ruíz-Moreno, F., Rodríguez-Sánchez, C., \& Turino, F. (2016). Percepción del profesorado y alumnado sobre la docencia en inglés: aplicación AICLE en la UA. In M.T. Tortosa, S. Grau, \& J. D. Álvarez (Eds.), Investigación, innovación y enseñanza universitaria: enfoques pluridisciplinares (pp. 353-368). Alicante, Spain: University of Alicante.

Savic, V. (2010). Are we ready for implementing CLIL in Primary language classrooms? Retrieved from http://www.britishcouncil.org/ro/serbia-elta-newsletter-2010-may.htm 
Sierra, L., \& López, A. (2015). CLIL en la formación inicial del profesorado de educación infantil y primaria: la experiencia del CES Don Bosco. Revista Educación y Futuro, 1, 1-23.

Tobalina, J. C., Carbonero, A., \& Martínez, M. (2017). El programa bilingüe a examen. Madrid: Acción Educativa.

62 Whittaker, R., Llinares, A., \& McCabe, A. (2011). Written discourse development in CLIL at secondary school. Language Teaching Research, 15, 343-362.

Yassin, S., Marsh, D., Tek, O., \& Ying, L. (2009). Learners' perceptions towards the teaching of science through English in Malaysia: A quantitative analysis. International CLIL Research Journal, 1, 54-69. 


\section{Appendix}

Por favor, responda a las siguientes preguntas con sinceridad. Los datos recogidos en esta encuesta serán utilizados exclusivamente para fines de investigación. Una vez rellenado, devuelva el documento a la misma dirección de correo desde donde se envió. Gracias por su colaboración.

\section{Datos personales y profesionales}

Edad Género

Asignatura que imparte en L2

Años de experiencia en AICLE

Formación académica (se refiere a la carrera universitaria que cursó)

¿Ha tenido algún tipo de experiencia profesional o académica en el extranjero? (Si su respuesta es afirmativa, indique el tiempo y tipo de estancia en el extranjero, ya sea experiencia profesional, académica)

¿Ha recibido algún tipo de formación metodológica en AICLE? (se refiere a cualquier tipo de curso dentro de la formación universitaria o posterior ya en carrera docente, que no se base en la lengua meta sino en la metodología para impartir docencia en un contexto AICLE)

\section{AICLE en el aula (marque la opción con la que se identifique utili- zando el formato de letra en negrita)}

En términos generales, ¿considera que la metodología AICLE se aplica de manera adecuada?

Sí No

En su caso particular, ¿considera que aplica la metodología AICLE de manera adecuada?

Sí No 
¿En qué situaciones utiliza la L1 con sus alumnos? Puede escoger más de una respuesta

Para resolver dudas

Extracurricularmente, para dirigirme a los alumnos dentro de clase Para explicar contenido

Nunca la utilizo

¿Qué tipo de actividades se realizan en clase? Puede escoger más de una respuesta

Actividades de respuesta múltiple

Actividades de unir con flechas

Actividades de rellenar huecos

Presentación oral

Debate

Otras (indique otras que no aparecen entre las opciones)

Además del libro de texto, ¿utiliza material adicional en clase? Si la respuesta es afirmativa, por favor, indique de qué tipo.

\section{Eficacia de AICLE}

¿Es AICLE eficiente para el aprendizaje de lengua extranjera y contenido? Señale una única opción.

Sí, tanto para el aprendizaje de la lengua extranjera como para el contenido

Sí, pero solamente para el aprendizaje de lengua extranjera Sí, pero solamente para el aprendizaje de contenido

No, ni para el aprendizaje de la lengua extranjera ni para el contenido

¿Estás de acuerdo con la siguiente afirmación? "El aprendizaje de contenido en una lengua extranjera puede ser tan profundo como el aprendizaje de ese contenido en lengua materna".

Sí No

¿Puede AICLE llegar a perjudicar el aprendizaje de contenido? Señale una única opción.

Sí

Solo en parte

No 